\title{
Türkiye'deki Kira Sertifikası (Sukuk) İhraçlarının Büyüme Üzerindeki Etkisine Dair Ampirik Bir Analiz: 2010-20191
}

\author{
Zeyneb Hafsa ORHAN (https://orcid.org/0000-0002-7515-910X), Department of Islamic Economics and \\ Finance, Istanbul Sabahattin Zaim University, Turkey; e-mail: hafsa.orhan@izu.edu.tr
}

Nurullah TIRMAN (https://orcid.org/0000-0002-8791-3069), Department of International Finance and Participation Banking, Istanbul Sabahattin Zaim University, Turkey; e-mail: tirman.nurullah@std.izu.edu.tr

\section{An Empirical Analysis Regarding the Effect of Sukuk Outstanding on Growth in Turkey: 2010-2019²}

\begin{abstract}
What is called Islamic finance today focuses on providing financial services in line with Islamic rules and ethos. Within the scope of Islamic finance developed since the 1970s, sukuk plays an essential role in Islamic banking (participation banking). In recent years, sukuk has also gained significant attention in Turkey. Despite its central role in Islamic banking and the increasing importance attached to it, the effects of sukuk on macroeconomic variables such as economic growth have not been studied in the literature extensively. Due to these reasons, this paper aims to conduct an econometric analysis about the effects of sukuk on Turkey's growth for the period of 2010-2019. The quarterly data is gathered from HMB (Treasure and Finance Ministry), TKBB (Participation Banks Association of Turkey), and MKK (Central Securities Depository of Turkey). ARDL bound test is utilized to examine the long-term effects of bonds and sukuk on economic growth. According to the results, both the governmental sukuk and the participation banking-based sukuk outstanding have statistically significant effects on Turkish growth. While the effect is positive for the former type, it is harmful to the latter. Nevertheless, for both types, the impact stays relatively minuscule. It is recommended that the governmental sukuk outstanding can be increased.
\end{abstract}

Keywords $\quad$ : Sukuk Outstanding's, Growth, Turkey, ARDL.

JEL Classification Codes: $\quad$ C32, E44, O47.

Öz

Dünyada İslâmî finans olarak anılan alan, İslâm'ın ilke ve etiğine uygun finansal hizmetler sunulmasına dayanmaktadır. Bu amaçla 1970'lerin sonundan itibaren geliştirilen bu yapı içerisinde bugün için en öne çıkan unsur, Türkiye'de katılım bankacılığı olarak bilinen İslâmî bankalardır. Bunu takiben ise yine Türkiye'de kira sertifikası olarak geçen, yurtdışında ise daha geniş anlamda sukuk olarak bilinen yapı gelmektedir. Kira sertifikası, Türkiye için de önemi giderek artan bir görünüm arz etmektedir. Fakat bu artan önemine rağmen kira sertifikalarının büyüme için ne derece önemli olduğuna dair gerek yabancı gerekse Türkçe literatürde fazla bir çalışma yapılmamıştır. Bunlardan hareketle bu makalenin amacı, İslâmî finans alanının giderek daha fazla öne çıkan bir unsuru olan kira

1 Özel sektör tarafindan ihraç edilen tahvil verileri Merkezi Kayıt Kuruluşu'ndan (MKK) bu çalışma kapsamında ücretsiz olarak alınmıştır. Bu bağlamda, Veri Depolama ve Raporlama Birimi nezdinde MKK'ya bu çalışmaya sağladıkları katkıdan dolayı teşekkür ederiz.

2 Data on bonds issued by the private sector has been received from the Central Securities Depository of Turkey (MKK) free of charge within the scope of this study. In this context, we would like to thank MKK, and especially the Unit of Data Storage and Reporting for their contribution to this study. 
sertifikası (sukuk) ihraçlarının büyüme üzerindeki etkisini 2010-2019 arası dönemde Türkiye için ekonometrik analize tabi tutmaktır. Çeyrek dönemlik veriler için Hazine ve Maliye Bakanlı̆̆ $($ HMB), Türkiye Katılım Bankaları Birliği (TKBB) ve Merkezi Kayıt Kuruluşu'ndan (MKK) faydalanılmıştır. Kira sertifikası ihraçlarının yanı sıra tahvillerin de karşılaştırmalı olarak ekonomik büyüme üzerindeki uzun dönemli ilişkisini incelemek için ARDL sınır testinden yararlanılmıştır. Analizden elde edilen sonuçlara göre hem devlet hem de katılım bankaları tarafından ihraç edilen sukukların büyüme üzerindeki etkisi anlamlı bulunmuştur fakat bunlardan ilkinin etkisi pozitif iken ikincisininki negatiftir. Her iki etki de rakamsal olarak ufak kalmıştır. Sonuçlardan hareketle özellikle devlet tarafından ihraç edilen kira sertifikalarına ağırlık verilmesi önerilebilir.

Anahtar Sözcükler $\quad$ : Kira Sertifikası (Sukuk), Büyüme, Türkiye, ARDL.

\section{Giriş}

\subsection{Arka Plan Bilgisi}

Ekonomiye dair kavramların, kurumların, politikaların İslâm'a uygun bir şekilde yapılandırılması fikrinden hareketle yola çıkan “İslâm İktisadı”, 20. yy’nin ilk yarısından itibaren gelişmiştir. Bu İslâm iktisadı fikri zamanla çeşitli sebepler dolayısıyla özellikle "İslâmî Finans" fikrine odaklanmıştır. İslâmî finans kısaca finansal kavram, kurum ve politikaların İslâm'a uygun bir şekilde yapılandırılması amacını taşımaktadır. İslâmî finansın öne çıkması özellikle 1970’lerin sonu itibariyle olmuştur.

İslâmî finans bugün 2 trilyon dolar üzerindeki hacmiyle dünya finansal büyüklüğünün yaklaşık \%1'ini oluşturmaktadır (IFSB, 2019). Her ne kadar bu oran çok yüksek olmasa da Avrupa'dan Afrika'ya kadar geniş bir coğrafyada varlığını sürdürmesiyle hayli yaygınlık kazanmış durumdadır. İslâmî finans, bugün için bünyesinde şu temel unsurları barındırmaktadır:

- İslâmî bankacılık,

- İslâmî sigortacılık (tekafül),

- İslâmî fonlar,

- Sukuk (İslâmî bono).

Bunlara ilave olarak İslâmî mikrofinans unsuru da eklenebilir. Listede yer alan unsurlardan İslâmî bankacılık, \%76'lık oranla İslâmî finansın bel kemiğini oluşturmaktadır. Onu, \%25'lik oranla sukuk izlemektedir (IFSB, 2019). Diğer iki unsurun ağırlığı ise görece daha azdir.

Bu makalenin konusunu oluşturan ve İslâmî bono olarak da adlandırılan sukuk kısaca şöyle tanımlanabilir: “... ticari bir varlığın menkul kıymetleştirilerek sertifikalar aracılığıyla satımıdır." (Aktepe, 2013: 147). Daha resmi bir tanım için, uluslararası İslâmî finans kurumu olan AAOIFI'nın (İslâmî Finans Kurumları için Muhasebe ve Denetim Kurumu, 2018) şu sukuk tanımına bakılabilir: Maddi varlıklar, kullanım hakkı ve hizmetlerin veya belirli bir proje ile özel yatırım aktivitesinin varlıklarının sahipliğindeki bölünmemiş hisseleri temsil eden eşit değerde sertifikalardır. 
Her ne kadar adı "İslâmî bono" olarak geçse de bilinen anlamıyla bono veya tahvilden temel farkı, faiz içermemesidir. Zira bilindiği üzere bono/tahvil, faizle borçlanma aracıdır. Sukuk ise bunun yerine herhangi düzenli gelir getiren bir varlığın ya da projenin menkul kıymetleştirilip sertifikalar halinde satılması işlemidir. Dolayısıyla, sertifika sahiplerinin elde edeceği dönemsel gelirler, faiz geliri değil, bahsi geçen varlık ya da projeye dayalı olarak elde edilen gelirlerden/getirilerden oluşmaktadır. Dolayısıyla sukuk, menkul kıymetleştirme mantığının daha farklı işlediği, varlığa-dayalı yatırım araçlarıdır. Bu farklılıklardan dolayı Onagun (2016), İslâmî bono yerine sukuk için "İslâmî yatırım sertifikaları" isminin daha uygun olduğunu dile getirmektedir.

Sukuk, yukarıda tanımlandığı şekliyle yeni bir finansal üründür. Her ne kadar sukuk kelimesinin tekil anlamını oluşturan sakk (vesika/sertifika), İslâmiyet'in ilk dönemlerinde kullanılmış olsa da bu uygulama, bugünkünden oldukça farklıdır. Sukukun bugünkü anlamıyla ilk ne zaman kullanıldığı net olmasa da Bayındır'a (2015) göre dünyadaki ilk sukuk uygulaması 1978'de Ürdün'de gerçekleştirilmiştir. Türkiye'deki ilk sukuk uygulamasını ise Kuveyt Türk Katılım Bankası 2010 yılında gerçekleştirmiştir. Bu bilgiden de anlaşılacağı üzere, sukuklar, banka gibi özel kurumlar tarafından çıkartılabilir (corporate sukuk). İlaveten, devlet de sukuk ihracı gerçekleştirebilir (sovereign sukuk).

Sukuk bugün Türkiye'de "kira sertifikası" olarak geçmektedir. SPK (Sermaye Piyasası Kurulu) 2010 yılında yayımlamış olduğu ilk tebliğ ile İslâmî finans literatüründe icare $^{3}$ sukuk modelini "sahipliğe dayalı kira sertifikası" olarak tanımlamıştır. Daha sonra SPK, 2013 yılında yayımladığı tebliğ ile Ortadoğu ve Malezya'daki sukuk modellerinden esinlenerek daha geniş kapsamlı sukuk yapılarından oluşan Türkiye'ye has bir model oluştursa da sukukun karşılığı olarak kira sertifikası terimini değiştirmemiştir. Bu tam olarak doğru bir tabir değildir, çünkü sukuk sadece icare modeline dayalı olmayıp alt yapısında hangi İslâmî finans ürününün kullanıldığına göre çeşitlilik göstermektedir ${ }^{4}$. Örneğin, dünyadaki ilk sukuk örneği ortaklık (mudarebe) sukuku şeklinde ihraç edilmiştir. Türkiye'de ise devlet hazinesi tarafından en çok sahipliğe dayalı (icare) sukuk tercih edilirken, özel sektör ve katılım bankaları tarafından ise en çok yönetim sözleşmesine dayalı (wakala/vekalet) sukuk yapısı tercih edilmektedir (Dede, 2017: 80). Bu bağlamda, Türkiye'de en çok tercih edilen kira sertifikası yapılarını incelemek için Şekil 1 ve Şekil 2'ye müracaat edilebilir.

3 İcare kelimesi Arapça'da e-c-r köküne dayanmakta ve ücret, kira gibi anlamlara gelmektedir.

4 Buna dair daha detaylı bilgi için bkz. <https://piyasarehberi.org/sozluk/sukuk>, 23.02.2020. 
Şekil: 1

Türkiye'de Uygulandığı Şekliyle Sahipliğe Dayalı Kira Sertifikası Yapısı

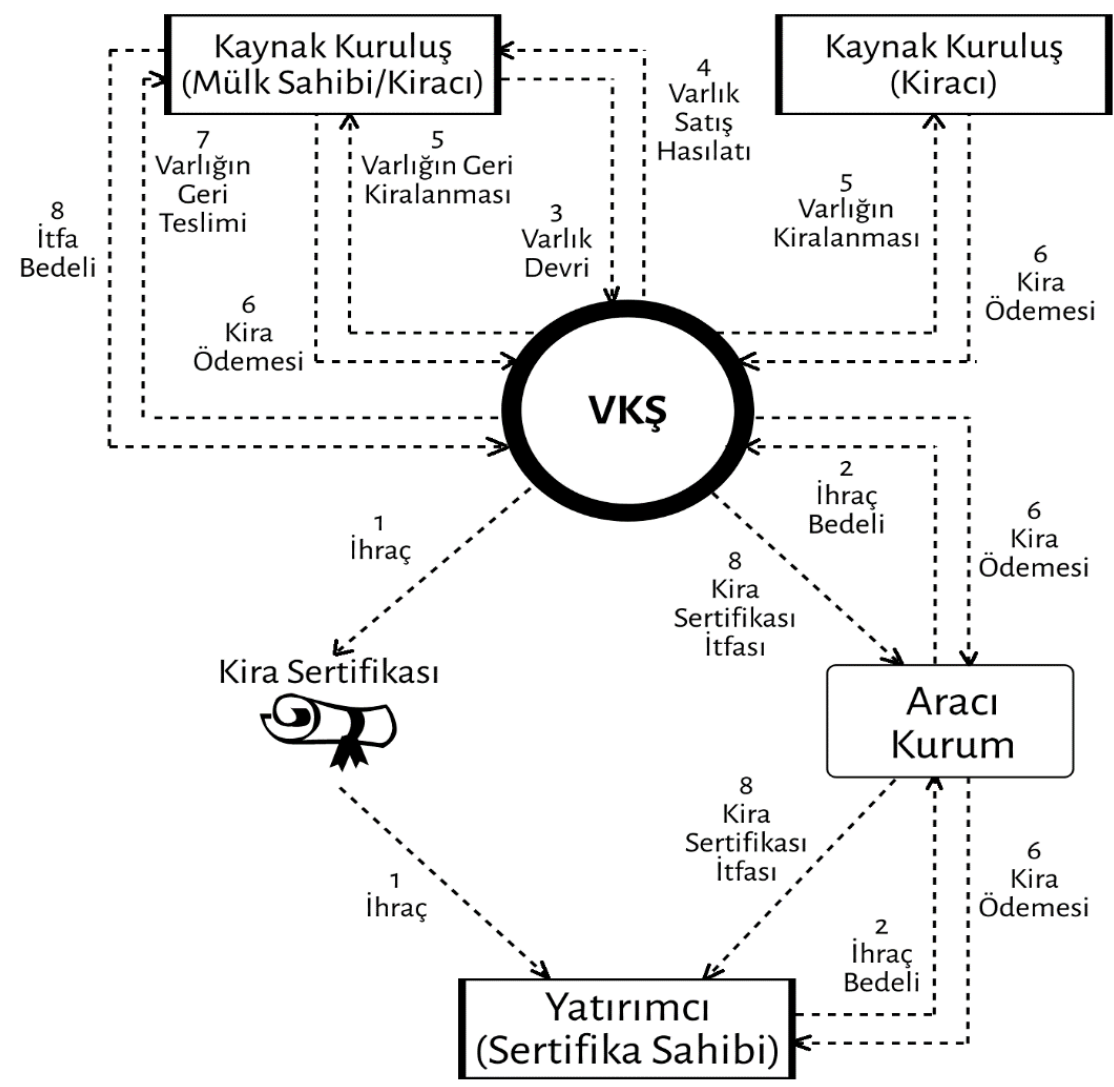

Kaynak: Yazarlar tarafindan hazırlanmıştır.

Şekil 1'de anlatılan sistemin işleyişi adım adım şunları kapsamaktadır:

1. Varlık Kiralama Şirketi (VKŞ) tarafindan yatırımcılara, sözleşmede belirtilen varlık(lar) kapsamında sahipliğe dayalı kira sertifikasının ihraç edilmesi,

2. VKŞ tarafindan yatırımcılardan ihraç bedelinin toplanması,

3. Sözleşmede belirtilen varlık/varlıkların Kaynak Kuruluş tarafından VKŞ'ye devri,

4. Yatırımcılardan toplanan ihraç bedelinin VKŞ tarafından Kaynak Kuruluşa aktarılması,

5. Varlığın VKŞ tarafindan Kaynak Kuruluşa geri kiralanması veya üçüncü tarafa kiralanması,

6. Kiralanan varlığın dönemsel kira getirisi,

7. Vade sonunda varlığın VKȘ tarafından mülkiyet sahibine geri devredilmesi,

8. Başlangıçta toplanan fonların yatırımcılara itfası. 
Şekil: 2

Türkiye'de Uygulandığı Şekliyle Yönetim Sözleşmesine Dayalı Kira Sertifikası Yapısı

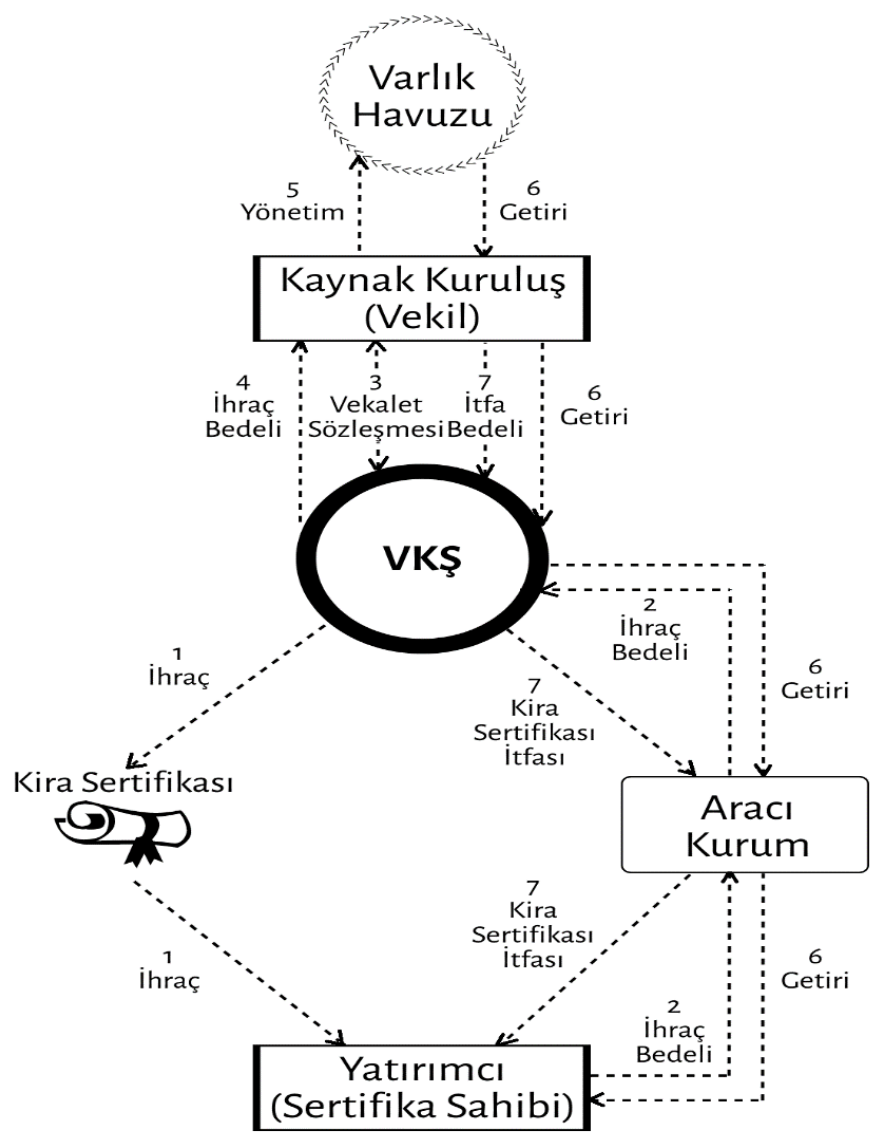

Kaynak: Yazarlar tarafindan oluşturulmuştur.

Şekil 2'de anlatılan sistemin işleyişi adım adım şunları kapsamaktadır:

1. VKŞ tarafından yatırımcılara, sözleşmede belirtilen varlık(lar) kapsamında yönetim sözleşmesine dayalı kira sertifikasının ihraç edilmesi,

2. VKŞ tarafından yatırımcılardan ihraç bedelinin toplanması,

3. Kaynak Kuruluş ile VKŞ arasında imzalanan vekalet sözleşmesi kapsamında Kaynak Kuruluşun VKŞ tarafindan vekil tayin edilmesi,

4. Yatırımcılardan toplanan ihraç bedelinin VKŞ tarafından Kaynak Kuruluşa aktarılmas1,

5. Kaynak Kuruluşun, yatırımcılardan elde ettiği fon ile oluşturduğu varlık havuzunu, yatırımcılar adına "vekil" sıfatıyla yönetmesi, 
6. Varlık havuzunun dönemsel getirisi,

7. Vade sonunda, başlangıçta toplanan fonların yatırımcılara itfası.

$\mathrm{Bu}$ gidişattan anlaşılacağı üzere, sukuk çıkaran şirketin ya da devletin temel amacı, toplu bir nakit para elde etmektir. Sukuk sahipleri ise sertifikaya konu olan varliktan elde edilen düzenli kira gelirini veya yönetim getirisini, sahip oldukları pay adedince almış olurlar. Bu, bonodaki faiz yerine elde edilen düzenli gelir kısmıdır. Dönemin sonunda ise yatırımcılar, sertifikaları alırken ödedikleri anaparayı geri alırlar. Tüm bu süreç, sukuk ihraç etmek üzere münhasıran kurulan VKŞ üzerinden finansal mühendislik yoluyla yürütülmektedir.

Gerek kiralama üzerine oturtulmuş sukuk, gerekse yönetim (wakala) sözleşmesine göre kurgulanmış sukuk veya diğer sukuk modelleri bütün dünyada benzer yapıda uygulanmaktadır. Bunların uygulamasındaki fıkhî problemler ayrıca tartışılmaktadır fakat bu konu, bu makalenin amacını aşmaktadır ${ }^{5}$.

Türkiye'deki kira sertifikası ihraçlarına dair veriler Tablo 1'den incelenebilir:

Tablo: 1

Türkiye'deki Kira Sertifikası İhraçları (TL) (2010-2019)

\begin{tabular}{|c|r|r|r|}
\hline Y1llar & Hazine Kira Sertifikası İhraçlar1 & Katılım Bankacıllı̆ 1 Sukuk İhraçlar1 & \multicolumn{1}{l|}{ TOPLAM } \\
\hline 2010 & 0,00 & $151.000 .000,00$ & $151.000 .000,00$ \\
\hline 2011 & 0,00 & $644.000 .000,00$ & 0,00 \\
\hline 2012 & $4.474 .482 .560,00$ & 0,000 & $4.474 .482 .560,00$ \\
\hline 2013 & $5.870 .126 .823,00$ & $1.440 .112 .773,23$ & $7.310 .239 .596,23$ \\
\hline 2014 & $5.432 .784 .070,00$ & $3.500 .118 .050,41$ & $8.932 .902 .120,41$ \\
\hline 2015 & $3.390 .299 .233,00$ & $4.323 .891 .000,00$ & $7.714 .190 .233,00$ \\
\hline 2016 & $9.162 .256 .540,00$ & $6.031 .113 .800,00$ & $15.193 .370 .340,00$ \\
\hline 2017 & $9.079 .329 .786,76$ & $7.208 .000 .000,00$ & $16.287 .329 .786,76$ \\
\hline 2018 & $78.145 .516 .190,49$ & $20.831 .174 .047,00$ & $98.976 .690 .237,49$ \\
\hline 2019 & $46.587 .837 .743,57$ & $41.919 .695 .953,00$ & $88.507 .533 .696,57$ \\
\hline
\end{tabular}

Kaynak: HMB (Hazine ve Maliye Bakanlı̆̆ı), TKBB (Türkiye Katılım Bankaları Birliği).

Tablo 1'den takip edilebileceği gibi hem hazine kira sertifikası hem de katılım bankalarının kira sertifikası ihraçları, 2010-2019 arası dönem için neredeyse her sene düzenli bir şekilde artmıştır. Özellikle son iki senedeki artış ise muazzam miktardadır. Son yıllardaki artışın en önemli sebebi 2016 yılında sukuk lehine yapılan vergisel düzenlemelerdir. Bunun yanı sıra, 2018 yılında BIST (Borsa İstanbul) nezdinde faaliyete geçen Taahhütlü İşlemler Pazarı, sukuk piyasasına farklı bir derinlik kazandırmıştır. Tablo 1 ile ilgili şu ilave bilgiler paylaşılabilir: Türkiye'de ilk sukuk ihracı, özel sektör tarafından yapılmıştır. Dolayısıyla 2010 ve 2011 seneleri için Hazine sukuk verilerinin 0 (sıfır) olması doğaldır. Ayrıca, 2018 senesi için, hazinenin sukuk ihraçları içerisinde özellikle Euro bazlı yurt içinde ihraç edilen sukuklar o yıl hazine tarafından ihraç edilen toplam sukuk hacminin yaklaşık \%59'unu oluştururken, 2019 senesi için ise dolar bazlı yurt dişına ihraç edilen Euro-sukuklar yaklaşık \%23'ünü oluşturmaktadır (HMB, 2020)6.

5 Buna dair ilave okumak yapmak isteyenler şu kaynağa müracaat edebilirler: Bayındır (2015).

6 HMB'den elde edilen veriler ile yazarlar tarafindan hesaplanmıştır. 


\subsection{Amaç ve Önem}

Bu makalenin amacı, Türkiye'deki kira sertifikalarının makroekonomik bir değişken olan ekonomik büyümeye etkisinin 2010-2019 yılları arasındaki dönem için ekonometrik analiz, özelde ARDL yöntemiyle incelenmesidir. Bu amacı gerçekleştirmek üzere takip edilecek olan yöntem ilgili bölümde detaylı bir şekilde açıklanacaktır.

$\mathrm{Bu}$ konunun önem arz etmesinin temel sebebi şudur: IFSB'nin (İslâmî Finansal Hizmetler Kurulu, 2019) son yayınladığı küresel rapordan hareketle görüleceği üzere son birkaç senedir İslâmî finans sektörünün içerisindeki payı azalan İslâmî bankacılığın yerine payı artan unsur, sukuk sektörüdür. Fakat bu önemi artan sektörün reel ekonomiye olan etkisi hemen hemen hiç incelenmemiş durumdadır. Bu konuda istisna oluşturan birkaç çalışmadan literatür bölümünde bahsedilecektir. Bunun yanı sıra ve yine bu hususla ilişkili olmak üzere, Tablo 1'den görüleceği üzere ülkemizde de önemi gittikçe artan sukuk ihraçlarının reel ekonomiye olan etkisine dair öncü çalışmalardan birisi gerçekleştirilmiş olacaktır.

\subsection{Kisitlar}

$\mathrm{Bu}$ çalışmanın temel kısıtı, ampirik analizde kullanılacak olan veri setine dair olan kısıttır. Zira Türkiye'de ihracına 2010 yılı itibariyle başlanan sukuklara dair veriler de ancak bu zaman diliminden itibaren mevcuttur. Bir başka kısıt, sukuk ihraçlarını gerçekleştiren yapılardan bir tanesi olan özel sektör evreninin tümünün çalışmaya dâhil edilememesidir. Fakat bunun yerine, yine Tablo 1'den takip edileceği üzere Türkiye için önemli bir sukuk ihraççısı olan katılım bankacılığı sukuk verileri kullanılacaktır.

\section{Literatür}

Bir önceki kısımda bahsedildiği gibi, konuyla ilgili çalışmalar oldukça az sayıdadır. Bunun temel sebebi, ilginç bir şekilde, literatürün tam tersi bir şeyi incelemeye odaklanmasıdır: Sukuk ihracını belirleyen (makro)ekonomik faktörlerin incelenmesi. Bu tarz çalışmalar için şunlara bakılabilir: (Al-Raeai vd., 2018; Hussain vd., 2018; Ahmad vd., 2012). Oysa reel ekonomiyle daha çok bağlantısı olduğu iddia edilen, hatta 2008 finansal krizini bu sebeple daha iyi bir şekilde atlattığı öne sürülen İslâmî finansın (Bashir, 2010) son dönemlerde öne çıkan bir unsuru olan sukukun reel sektör üzerindeki etkilerini incelemek çok daha elzemdir.

Sukuk ihraçlarının büyüme ve kalkınma/gelişme üzerindeki etkilerine dair olan az sayıdaki çalışma şu iki gruba ayrılabilir: Ekonometrik veya istatistiksel bir yöntem takip etmeyenler ve edenler. İlkine örnek olarak Kantarcı ve Eren'in (2018) sukuk piyasasının ekonomik etkilerine dair kaleme aldığı yazı verilebilir. Zira herhangi bir ampirik analizin yapılmadığı yazıda, sukukun temel özelliklerinden hareketle şu gibi olumlu etkileri olmasının bekleneceği dile getirilmiş, bunlar ayrıca test edilmemiştir: Ekonomik büyüme, ekonomik istikrar, enflasyon ve istihdam. Son üç unsur zaten ekonomik büyümeyle de doğrudan ilgisi olan unsurlardır. Bu gruba dâhil edilebilecek bir başka çalışma, Onagun'un (2016) sukuk ihraçlarının Birleşik Arap Emirlikleri ekonomisi üzerindeki etkisine dair hazırladığı yazıdır. Sukukun NASDAQ (The National Association of Securities Dealers 
Automated Quotations) üzerinden ihracına dair bilgiler paylaşılan yazıda, bir öncekindeki gibi olumlu etki varsayımında bulunulmuş, bunun test edilmesine girişilmemiştir.

İkinci gruba dâhil edilebilecek çalışmalar için ilk örnek, Smaoui ve Mechi (2017) tarafından hazırlanan çalışmadır. Sukuk ihraç eden bütün ülkelerin 1995-2015 arası verilerine dayanılarak hazırlanan çalışmada dönemler 1995-1997, 1998-2000 gibi üçer yıllık periyotlara ayrılıp ortalama değerler alınmıştır. Çalışmada yer alan ülkelerden biri de Türkiye'dir. Bu durum akıllara şu soruyu getirmektedir: Türkiye sukuk ihraçlarına 1995'ten oldukça sonra başlamıştır. Türkiye gibi olan ülkeler için veri seçimi nasıl yapılmıştır? Bu sorunun cevabının açıkça verilmediği çalışmada panel veri analizi yapılmış, büyümeyi etkileyebilecek çeşitli kontrol değişkenlerle beraber sukukun hem devlet tarafindan ihraç edilen hali hem de özel sektör sukukunun etkisi regresyon analiziyle ortaya konulmaya çalışılmıştır. Neticede, sukuk piyasasının gelişmişliğinin uzun dönemli ekonomik büyümeyi stimüle edici ciddi bir etkisi olduğu bulgusuna ulaşılmıştır. Echchabi vd. (2016) tarafından hazırlanan benzer bir çalışmada Türkiye'nin de dâhil olduğu 17 ülkenin 2005-2012 arası verilerine dayanılarak sukuk ihraçlarının büyüme, brüt sermaye oluşumu ve ihracat-ithalat rakamları üzerindeki etkisi incelenmiştir. Fakat üç ayrı regresyon modelinin kurulduğu yöntemde herhangi bir kontrol değişkenine yer verilmemiştir. Tek bağımsız değişken olarak sukuk ihraçları alınmıştır. Neticeye göre Suudi Arabistan hariç diğer ülkeler için pozitif bir etki saptanmıştır.

Türkiye'nin doğrudan ele alınmayıp başka ülkelerle (kalkınmakta olan 8 ülkeyle birlikte) ele alındığı bir başka çalışma, Yıldırım vd. (2020) tarafından hazırlanmıştır. 2014 1. çeyreği ile 2017 4. çeyreği arasındaki verileri kapsayan çalışmada enflasyon, ticaret açı̆̆ gibi kontrol değişkenlerin yanı sıra sukuk ihraçlarının herhangi bir yapısal ve dönemsel ayrıma tabi tutulmadan büyüme üzerindeki etkisi regresyon yöntemiyle bulgulanmaya çalışılmıştır. Türkiye için ayrıca çıkarım yapılmayan çalışmada genel itibariyle sukuk piyasası ile büyüme arasında pozitif bir ilişki bulunmuştur.

Bundan önceki üç çalışmada olduğu gibi Türkiye dâhil çeşitli ülkeleri (toplamda 8 ülke) kapsamak üzere Smaoui ve Mechi’nin (a.g.e.) çalışmasındaki gibi panel veri analizi kullanan bir başka ilgili çalışma, Avci (2020) tarafından hazırlanmıştır. Dumitrescu Hurlin panel nedensellik testinin kullanıldığı çalışmada 2014 1. çeyreği ile 2019 2. çeyreği arasındaki verilere yer verilmiş ve sonuçta ekonomik büyümeden sukuk büyüme oranına doğru tek yönlü nedensellik bulgulanmıştır. Bu da sukuk sektörünün büyümeye etkisinin bulgulanamadığını göstermektedir. Bu çalışmada da Türkiye özelinde sonuç paylaşımı yapılmamıştır.

Bu noktada doğrudan Türkiye için bulabildiğimiz tek çalışma, Alkhawaja (2019) tarafından hazırlanan çalışmadır. Bu çalışma çerçevesinde 2010-2017 arası sukuk ihraçlarına dair veriler kullanılmıştır. Fakat bu verilerle herhangi bir ekonometrik analiz gerçekleştirilmemiş, yalnızca her senedeki sukuk ihraçlarının GSYİH'ye (Gayri Safi Yurtiçi Hasıla) oranları bulunup bunların seyri izlenmiştir. Neticede \%0.013'ten \%0.544'e uzanan bir artış olduğu vurgulanmıştır. 
Sukukun büyüme üzerindeki etkisinin tekil örnekler üzerinden özellikle incelendiği bir ülke, Endonezya' dır. Mitsaliyandito vd. (2017), 2009-2016 arası çeyrek dönemlik veriler kullanıp sukuk türlerinin Endonezya'nın ekonomik büyümesi üzerindeki etkilerini incelemişlerdir. Bunu yaparken VAR yöntemini kullanmışlardır. Sonuca göre sukuk, özellikle de devlet tarafından basılan sukuk, büyüme üzerinde olumlu etki yapmaktadır. Endonezya'ya dair bir başka çalışma, Fahrian ve Seftarita (2016) tarafından hazırlanmıştır. 2009-2015 arası çeyrek dönemlik verilerin kullanıldığı çalışmada ARDL (Autoregressive Distributed Lag) modeli kullanılmış ve sonuçta kısa dönemde olumlu bir etki söz konusu olsa da etkinin büyüklüğünün az olduğu bulgulanmıştır.

Her ne kadar ekonometrik olmasa da ampirik bir yöntem kullanan Malikov (2017), yeterince doğrudan veri elde edilemeyeceğinden hareketle Malezya ve Suudi Arabistan'daki bazı makroekonomik değişkenlerin sukuk ihracı öncesi ve sonrası değerlerini t-testine tabi tutup herhangi bir anlamlı değişiklik ortaya çıkıp çıkmadığını test etmiştir. Fakat incelediği dönemlerde söz konusu makroekonomik değişkenlere -ki bunlardan bir tanesi kişi baş1 büyüme oranıdır- etki eden çok fazla etmen söz konusudur. Bunun sonuçları nasıl etkileyeceği bir tarafa bırakılacak olursa yazar, her iki ülke için de olumlu, anlamlı etki bulgulamıştır.

Paylaşılan çalışmalardan anlaşılacağı üzere, Türkiye özelinde herhangi bir detaylı çalışma mevcut değildir. Bu makale bu açığı giderme amacını taşımaktadır. İkinci olarak, çalışmalar ele alınırken dile getirilen yöntemsel soru işaretlerine özellikle dikkat edilecektir.

\section{Yöntem}

Türkiye'de ihraç edilen sukukların ekonomik büyümeye etkisini ampirik olarak incelemek amacıyla ilave açıklayıcı ve kontrol değişkenlerle birlikte 2010-2019 yılları arası çeyrek dönemlik zaman serileri kullanılmıştır. HMB (Hazine ve Maliye Bakanlığı), MKK (Merkezi Kayıt Kuruluşu), TCMB (Tükiye Cumhuriyet Merkez Bankası), TKBB (Türkiye Katılım Bankaları Birliği) ve TÜİK'ten (Türkiye İstatistik Kurumu) alınan on bir farklı veri seti model kapsamında uyarlanarak çalışmada kullanılan on bir değişkenin zaman serileri elde edilmiştir. Çalışmada, hazine veya özel sektör tarafindan ihraç edilen sukuk ve tahvillerin nominal değerleri dikkate alınırken, döviz veya altın cinsinden değeri mevcut çeyrek dönem kur oranları üzerinden TL baz değerince analize dahil edilmiştir.

Zaman serisi analizlerinde, değişkenler arasındaki uzun dönemli ilişkinin incelenmesinde eşbütünleşme testlerinden yararlanılmaktadır. Eşbütünleşme testlerinde değişkenlerin aynı dereceden bütünleşik olması gerekir (Enders, 1995) ki bu da incelemelerde eşbütünleşme testleri için bir kısıttır. Ancak, Pesaran ve Shin (1999), ARDL modelinin eşbütünleşme testi için kullanılabileceğini göstermişler ve bu bağlamda Pesaran vd. (2001) tarafından sınır (bounds) testi geliştirilmiştir. Sınır testi için, diğer eşbütünleşme testlerinden farklı olarak, bütünleşme özelliği dikkate alınmamaktadır (Çil, 2018). Başka bir deyişle sınır testi sınaması, değişkenlerin $\mathrm{I}(0)$ veya $\mathrm{I}(1)$ dereceden bütünleşik olup olmadığına bakılmaksızın yapılmaktadır. Sınır testi, ARDL modeline dayandığından ve ARDL model ile çoklu değişkenler arasında dağıtılmış gecikme sağlanabildiğinden dolayı 
bu çalışma kapsamında ARDL modeli kullanılmıştır. Bu doğrultuda çalışmada uygulanacak modelin eşitliği Denklem 1'deki gibidir.

$$
\begin{aligned}
& \Delta Y_{t}=\beta_{0}+\sum_{i=1}^{p} \beta_{1 i} \Delta Y_{t-i}+\sum_{i=0}^{m} \beta_{2 i} \text { HSuk }_{t-i}+\sum_{i=0}^{n} \beta_{3 i} \text { HTah }_{t-i}+ \\
& \sum_{i=0}^{k} \beta_{4 i} \text { KBSuk }_{t-i}+\sum_{i=0}^{l} \beta_{5 i} \text { OSTah }_{t-i}+\sum_{i=0}^{q} \beta_{6 i} \text { Kredi }_{t-i}+\varphi_{1} \text { Enf }_{t}+\varphi_{2} \text { Tuk }_{t}+ \\
& \varphi_{3} \text { BSO }_{t}+\varphi_{4} D H_{t}+\varphi_{5} N D T_{t}+\mu_{t}
\end{aligned}
$$

Denklem 1'de de görüldüğü üzere model on bir farklı değişkeni içermektedir. Denklem eşitliğinin sağ tarafını oluşturan değişkenleri iki grupta toplamak mümkündür. İlk grupta bağımlı değişkenin ve beş farklı dinamik dişsal değişkenin yer aldığı açıklayıcı değişkenlerin farkları ve bu farkların gecikmeleri yer almaktadır. Bu grupta sadece bağımlı değişkenin farkı birinci gecikmeden başlarken diğer dışsal açıklayıcı değişkenler ise sıfır dereceli gecikmeden başlamaktadır. İkinci grubu ise kontrol değişkenler oluşturmaktadır. Bu değişkenleri tanımlayıcı özellikler Tablo 2'de yer almaktadır.

Tablo: 2

\section{Değişkenlerin Tanımlayıcı Özellikleri}

\begin{tabular}{|l|l|l|c|}
\hline Değişken & Sembol & Veri Seti & Kaynak \\
\hline Ekonomik Büyüme & $\Delta Y$ & Harcama yöntemiyle 2009 bazlı zincirlenmiş hacim GSYİH değişim oranı & TÜIK \\
\hline Hazine Sukuk İhracı & HSuk & $\begin{array}{l}\text { Hazine tarafından yurt içinde ve yurt dışında ihraç edilen kira sertifikalarının TL cinsinden toplam } \\
\text { değeri }\end{array}$ & HMB \\
\hline Hazine Tahvil İhracı & HTah & Hazine tarafından yurt içinde ve yurt dışında ihraç edilen tahvillerin TL cinsinden toplam değeri & HMB \\
\hline $\begin{array}{l}\text { Katılım Bankaları } \\
\text { Sukuk İhracı }\end{array}$ & OSSuk & Katılım bankaları tarafından ihraç edilen kira sertifikalarının TL cinsinden değeri \\
\hline $\begin{array}{l}\text { Özel Sektör Tahvil } \\
\text { İhracı }\end{array}$ & OSTah & Özel sektör tarafından ihraç edilen tahvilatın TL cinsinden değeri & TKBB \\
\hline Krediler & Kredi & TL cinsinden toplam kredi hacmi & MKK \\
\hline Enflasyon & Enf & Çeyrek dönemlik ortalamalara göre hesaplanmış TÜFE oranı & TCMB \\
\hline Tüketim & Tuk & $\begin{array}{l}\text { Cari Fiyatlarla hanehalkı ve hane halkına hizmet eden kâr amacı olmayan kuruluş tüketiminin } \\
\text { GSYİH'deki payı }\end{array}$ \\
\hline Brüt Sermaye Oluşumu & BSO & Cari fiyatlarla gayrisafi sabit sermaye oluşumunun GSYİH'daki payı & TÜIKK \\
\hline Devlet Harcamaları & DH & Devletin nihai tüketim harcamaları ile vergi-subvansiyon farkının GSYİH'daki payı & TÜİK \\
\hline Net Dış Ticaret & NDT & Net ihracatın GSYİH'daki payı & TÜİK \\
\hline
\end{tabular}

Kaynak: HMB, MKK, TCMB, TKBB, TÜIK (2010/1.Ç-2019/4.Ç).

Verilen bilgiler doğrultusunda, Denklem 1'deki gibi ARDL modeli kapsamında ele alınan değiş̧kenler arası uzun dönemli ilişkinin incelenmesi için yapılan sınır testi eşitliği Denklem 2'deki gibidir.

$$
\begin{aligned}
& \Delta Y_{t}=\beta_{0}+\sum_{i=1}^{p} \beta_{1 i} \Delta Y_{t-i}+\sum_{i=0}^{m} \beta_{2 i} \text { HSuk }_{t-i}+\sum_{i=0}^{n} \beta_{3 i} \text { HTah }_{t-i}+ \\
& \sum_{i=0}^{k} \beta_{4 i} \text { KBSuk }_{t-i}+\sum_{i=0}^{l} \beta_{5 i} \text { OSTah }_{t-i}+\sum_{i=0}^{q} \beta_{6 i} \text { Kredi }_{t-i}+\delta_{1} \Delta Y_{t-1}+\delta_{2} \text { HSuk }_{t-1}+ \\
& \delta_{3} \text { HTah }_{t-1}+\delta_{4} \text { KBSuk }_{t-1}+\delta_{5} \text { OSTah }_{t-1}+\delta_{6} \text { Kredi }_{t-1}+\mu_{t}
\end{aligned}
$$

Bağımlı ve bağımsız değişkenler arasındaki uzun dönemli ilişkinin test hipotezi aşağıdaki gibidir:

$$
\begin{aligned}
& H_{0}: \delta_{1}=\delta_{2}=\delta_{3}=\delta_{4}=\delta_{5}=\delta_{6}=0 \rightarrow \text { Eşbütünleşme Yoktur } \\
& H_{1}: \delta_{1} \neq \delta_{2} \neq \delta_{3} \neq \delta_{4} \neq \delta_{5} \neq \delta_{6} \neq 0 \rightarrow \text { Eşbütünleşme Vardır }
\end{aligned}
$$

7 TÜIK, GSYIH verilerini, harcama yöntemi, üretim yöntemi ve gelir yöntemi ile hesaplama yöntemleriyle sunmaktadir. 
Modelin Wald testi $\mathrm{F}$ istatistiği ile hipotezler sınanmaktadır. Elde edilen sonuç Pesaran vd. (2001) tarafından geliştirilen alt sınır I(0) ve üst sınır I(1) anlamlılık düzeyleri ile karşılaştırılarak sınanmaktadır. Wald $\mathrm{F}$ istatistik değeri $\mathrm{I}(1)$ değerinden büyükse $H_{0}$ reddedilmektedir, yani eşbütünleşme vardır. Diğer bir ifadeyle, değişkenler arası uzun dönemli ilişkinin varlığı kabul edilmektedir.

Ekonomik çıktının makroekonomik belirleyicileri tüketim, yatırım, devlet harcamaları ve net dış ticaret dengesidir. Hazinenin ihraç ettiği sukuk ve tahviller, yatırım ve devlet harcamalarını etkilemektedir. Diğer yandan özel sektörün ihraç etmiş olduğu sukuk ve tahviller ise yatırım ve dış ticareti etkilemektedir. Krediler ise tüketim, yatırım ve dış ticareti etkilemektedir. Dolayısıyla modelde yer alan dinamik açıklayıcı değişkenler, ekonomik büyüme ile dolaylı olarak ilişki içindedir. Kontrol değişkenler ise ekonomik büyümenin fonksiyonunu oluşturmaktadır. Buradan yola çıarak Türkiye'de ihraç edilen sukukun, ekonomik büyüme üzerindeki etkisi incelenirken tüm parametreler göz ard1 edilmeden modele dâhil edilmiştir. Bu sayede, sukukun diğer finansman araçları (kredi ve tahvil gibi) ile mukayeseli analizi de yapılabilecektir.

$\mathrm{Bu}$ bağlamda çalışma modelinde öncelikle değiş̧kenlere ait verilerin durağan olup olmadığını ölçmek için Augmented Dickey Fuller (ADF) birim kök testi yapılmıştır. Durağan hale getirilen veriler ile ARDL regresyon modeli oluşturulmuştur. Sonrasında, oluşturulan modelin sınanmasında şu testlerden yararlanılmışıı: Otokorelasyon durumunu ortaya çıkarmak için Breusch-Godfrey testi, değişen varyans varsayımını incelemek için White test, kontrol değişkenlerin anlamlılığını ölçmek için Ramsey RESET testi ve modelin tahmin dönemindeki kararlılı̆ııı incelemek için de CUSUM ve CUSUM of Square testleri. Son olarak eşbütünleşme testi için Sınır (Bounds) testi yapılarak modelin kısa dönem ve uzun dönem ilişkileri incelenmiştir. İlgili bulgular bir sonraki bölümde yer almaktadır.

\section{Ampirik Sonuçlar}

Bir önceki bölümde bahsi geçtiği üzere, Denklem 2'de ortaya konan model için ilkin ADF birim kök testi yapılmıştır. İlgili sonuçlar Tablo 3 'te yer almaktadır. 
Tablo: 3

ADF Birim Kök Testi Sonuçları

\begin{tabular}{|c|c|c|c|c|}
\hline & \multicolumn{2}{|c|}{ Düzey } & \multicolumn{2}{|c|}{ 1. Fark } \\
\hline & t-istatistiğ $i$ & Olasılık* & t-istatistiği & Olasılık \\
\hline$\Delta \mathrm{Y}$ & $-2,515076$ & 0,1197 & $-5,728647$ & 0,0000 \\
\hline HSuk & $-3,484540$ & 0,0139 & & \\
\hline HTah & $-4,268010$ & 0,0017 & & \\
\hline KBSuk & 2,301528 & 0,9999 & $-7,504159$ & 0,0000 \\
\hline OSTah & 0,699700 & 0,9906 & $-5,269125$ & 0,0001 \\
\hline Kredi & 0,938373 & 0,9950 & $-7,283178$ & 0,0000 \\
\hline Enf & $-0,158395$ & 0,9354 & $-4,086313$ & 0,0030 \\
\hline Tuk & $-0,137316$ & 0,9375 & $-10,11094$ & 0,0000 \\
\hline BSO & $-2,018045$ & 0,2781 & $-3,059217$ & 0,0394 \\
\hline $\mathrm{DH}$ & $-3,288927$ & 0,0231 & & \\
\hline NDT & $-0,914678$ & 0,7713 & $-4,321007$ & 0,0017 \\
\hline
\end{tabular}

*\%5 anlamlılık düzeyine göre anlamlılı̆̆ ifade etmektedir.

Buna göre, bütün değişkenler serbest düzeyde $\mathrm{I}(0)$ veya birinci farkta $\mathrm{I}(1)$ durağan hale gelmiştir. Bunun ardından gerçekleştirilen ARDL model tahmini sonuçları ise Tablo 4 'te yer almaktadır.

Tablo: 4

ARDL (1,2,0,2,0,3) Model Tahmini

\begin{tabular}{|c|c|c|c|c|}
\hline Değişken & Katsay1 & Standart Hata & t-istatistiği & Olasılık \\
\hline $\mathrm{d} \Delta \mathrm{Y}(-1)$ & $-0,6025290000$ & 0,1330480000 & $-4,528644$ & 0,0003 \\
\hline HSuk & 0,0000000001 & 0,0000000001 & 0,965692 & 0,3477 \\
\hline HSuk (-1) & $-0,0000000001$ & 0,0000000001 & $-1,043859$ & 0,3112 \\
\hline HSuk (-2) & 0,0000000004 & 0,0000000001 & 4,022104 & 0,0009 \\
\hline HTah & 0,0000000000 & 0,0000000000 & 0,328198 & 0,7468 \\
\hline dKBSuk & $-0,0000000013$ & 0,0000000005 & $-2,633701$ & 0,0174 \\
\hline dKBSuk (-1) & $-0,0000000011$ & 0,0000000005 & $-2,084911$ & 0,0525 \\
\hline dKBSuk (-2) & $-0,0000000017$ & 0,0000000005 & $-3,543087$ & 0,0025 \\
\hline dOSTah & 0,0000000000 & 0,0000000002 & $-0,13865$ & 0,8914 \\
\hline dKredi & 0,0000000140 & 0,0000000081 & 1,734004 & 0,101 \\
\hline dKredi (-1) & 0,0000000241 & 0,0000000111 & 2,162413 & 0,0451 \\
\hline dKredi (-2) & 0,0000000238 & 0,0000000130 & 1,834657 & 0,0841 \\
\hline dKredi $(-3)$ & $-0,0000000200$ & 0,0000000106 & $-1,885279$ & 0,0766 \\
\hline dEnf & $-1,0351150000$ & 0,5647190000 & $-1,832974$ & 0,0844 \\
\hline dTuk & $-1,1308690000$ & 0,3390420000 & $-3,335481$ & 0,0039 \\
\hline $\mathrm{dBSO}$ & $-0,5078510000$ & 0,2977990000 & $-1,705348$ & 0,1063 \\
\hline $\mathrm{DH}$ & 0,1402090000 & 0,5580240000 & 0,251261 & 0,8046 \\
\hline dNDT & $-1,4033410000$ & 0,3881560000 & $-3,615405$ & 0,0021 \\
\hline $\mathrm{C}$ & $-6,4722370000$ & 14,8934200000 & $-0,43457$ & 0,6693 \\
\hline \multicolumn{5}{|c|}{ Tanımlayıcı İstatistikler } \\
\hline $\mathrm{R}^{2}$ & 0,807688 & ${\text { Düzeltilmiş } \mathrm{R}^{2}}$ & & 0,604064 \\
\hline F-istatistiği & 3,966559 & Olasılık (F-istatistiği) & & 0,003272 \\
\hline Schwarz Kriteri & 5,230396 & Durbin-Watson & & 2,093101 \\
\hline
\end{tabular}

ARDL $(1,2,0,2,0,3)$ modeli gecikme uzunlukları Schwarz kriterine göre belirlenmiştir. Bu doğrultuda, Tablo 4'ten çıkan temel sonuçlar şunlardır: Öncelikle, ARDL model tahmini \% $80 \mathrm{R}$-square değeriyle birlikte açıklayıcı bir model ortaya koymuştur. İkinci olarak, hazine tahvili (HTah), özel sektörü tahvili (OSTah), brüt sermaye oluşumu (BSO), devlet harcamaları (DH) ve sabit terim (C), hem $\% 5$ hem de \%10'luk anlamlılik düzeyinde istatistiksel olarak anlamsız çıkmıştır. Burada göze çarpan bir sonuç, tahvillerin büyüme üzerinde anlamlı bir etkisi olmadığı sonucudur. Buna dair tartışmalara bir sonraki bölümde yer verilecektir. 
Tablo 4'ten hareketle elde edilen bir başka önemli sonuç gerek hazine sukukunun gerekse de özel sektör sukukunun büyüme üzerindeki etkisinin ikinci gecikme uzunluğu alındığında \%5 düzeyinde anlamlı oluşudur. Bunlardan ilki pozitif bir etkiye sahipken ikincisi negatif bir etkiye sahiptir. Buna dair tartışmalara da bir sonraki bölümde yer verilecektir. Bu modelin sınamasını yapmak için yapılan gerekli tanısal testlerin sonuçları Tablo 5'te paylaşılmaktadır.

Tablo: 5

\section{Tanısal (Diagnostik) Testler}

\begin{tabular}{|l|r|r|}
\hline Test & İstatistik & Olasilık* \\
\hline Breusch-Godfrey (-1) Otokorelasyon Testi & 0,300803 & 0,5910 \\
\hline Breusch-Godfrey (-2) Otokorelasyon Testi & 0,4661 \\
\hline Breusch-Godfrey (-3) Otokorelasyon Testi & 0,803503 & 0,909215 \\
\hline White Değişen Varyans Testi & 0,544354 & 0,716095 \\
\hline Ramsey RESET Test (5) & 0,8948 \\
\hline
\end{tabular}

*\%5 anlamlılık düzeyine göre anlamlılı̆̆ ifade etmektedir.

Buna göre ARDL modeli kapsamında Schwarz kriterine göre belirlenen üç gecikme uzunluğu için de herhangi bir otokorelasyon problemi söz konusu değildir. Sonrasında yapılan White test sonuçlarına göreyse, hata terimi varyansı bağımsız değişkenlere bağlı olarak değişmemektedir. Dolayısıyla, model değişen varyans sorunu taşımamaktadır. Son olarak, modele kontrol değişken olarak eklenen beş değişkenin anlamlılığı Ramsey RESET test sonuçları ile ortaya konmuştur.

Şekil: 3

CUSUM ve CUSUMSQ Grafiği

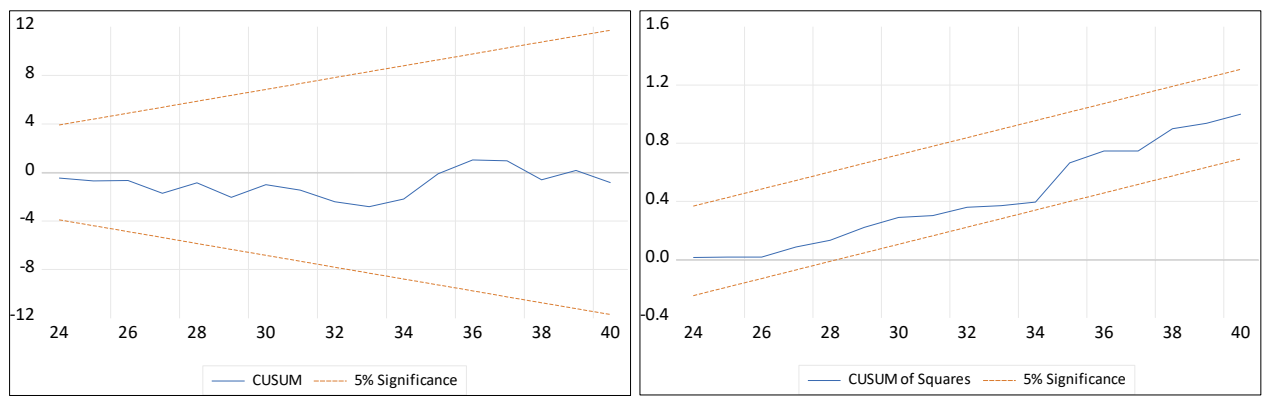

Modelin tahmin dönemindeki kararlılığını incelemek için CUSUM ve CUSUM of Square testleri yapılmıştır. Şekil 3 'ten de görüldüğü üzere model, alt ve üst sınır çizgileri içerisinde yer almaktadır. Buna göre, modelin tahmin döneminde kararlı olduğu, yani herhangi bir yapısal kırılmanın olmadığı görülmektedir.

Ardından, eşbütünleşme testi için ARDL sınır (Bounds) testi yapılmış ve böylece modelin kısa dönem ve uzun dönem ilişkileri incelenmiştir. Sonuçları Tablo 6'da görülen testlerden hareketle F-istatistiği I(1) değerinden büyük olduğu için farksızlık hipotezi $\mathrm{H}_{0}$ reddedilmektedir, dolayısıyla arada uzun dönemli bir ilişkinin olduğu görülmektedir. 
Tablo: 6

ARDL Sınır Testi Sonuçları

\begin{tabular}{|c|c|c|c|c|}
\hline & & Anlamlılık Düzeyi & $\mathrm{I}(0)$ & $\mathrm{I}(1)$ \\
\hline F-istatistiği & 22,269291 & $\% 10$ & 2,08 & 3,00 \\
\hline $\mathrm{k}$ & 5 & $\% 5$ & 2,39 & 3,38 \\
\hline & & $\% 2,5$ & 2,70 & 3,73 \\
\hline & & $\% 1$ & 3,06 & 4,15 \\
\hline
\end{tabular}

Nitekim bir adım sonrasında bununla bağlantılı olmak üzere kısa ve uzun dönem katsayılarına göre yeniden modelleme yapılmıştır. Sonuçlar Tablo 7'dedir.

Tablo: 7

Kısa Dönem ve Uzun Dönem Katsayıları

\begin{tabular}{|c|c|c|c|c|}
\hline \multicolumn{5}{|c|}{ Kısa Dönem Katsayıları ve Hata Düzeltme Modeli } \\
\hline Değişken & Katsayı & Standart Hata & t-istatistik & Olasılık \\
\hline $\mathrm{C}$ & $-6,47223700000$ & $\begin{array}{r}14,89342000000 \\
\end{array}$ & $-0,43457$ & $\begin{array}{r}0,6693 \\
\end{array}$ \\
\hline $\mathrm{dY}(-1)$ & $-1,60252900000$ & 0,13304800000 & $-12,04471$ & 0,0000 \\
\hline HSUK(-1) & 0,00000000035 & 0,00000000009 & 3,765989 & 0,0015 \\
\hline HTAH & 0,00000000001 & 0,00000000004 & 0,328198 & 0,7468 \\
\hline dKBSUK(-1) & $-0,00000000411$ & 0,00000000123 & $-3,337768$ & 0,0039 \\
\hline dOSTAH & 0,00000000002 & 0,00000000017 & $-0,13865$ & 0,8914 \\
\hline dKREDI(-1) & 0,00000004200 & 0,00000001780 & 2,363614 & 0,0303 \\
\hline $\mathrm{d}(\mathrm{HSUK})$ & 0,00000000008 & 0,00000000008 & 0,965692 & 0,3477 \\
\hline $\mathrm{d}(\operatorname{HSUK}(-1))$ & $-0,00000000040$ & 0,00000000010 & $-4,022104$ & 0,0009 \\
\hline d(DKBSUK) & $-0,00000000129$ & 0,00000000049 & $-2,633701$ & 0,0174 \\
\hline d(DKBSUK $(-1))$ & 0,00000000170 & 0,00000000048 & 3,543087 & 0,0025 \\
\hline $\mathrm{d}(\mathrm{DKREDI})$ & 0,00000001400 & 0,00000000808 & 1,734004 & 0,1010 \\
\hline d(DKREDI(-1)) & $-0,00000000385$ & 0,00000001870 & $-0,205362$ & 0,8397 \\
\hline d(DKREDI(-2)) & 0,00000002000 & 0,00000001060 & 1,885279 & 0,0766 \\
\hline dENF & $-1,03511500000$ & 0,56471900000 & $-1,832974$ & 0,0844 \\
\hline dTUK & $-1,13086900000$ & 0,33904200000 & $-3,335481$ & 0,0039 \\
\hline dBSO & $-0,50785100000$ & 0,29779900000 & $-1,705348$ & 0,1063 \\
\hline $\mathrm{dH}$ & 0,14020900000 & 0,55802400000 & 0,251261 & 0,8046 \\
\hline dNDT & $-1,40334100000$ & 0,38815600000 & $-3,615405$ & 0,0021 \\
\hline \multicolumn{5}{|c|}{ Uzun Dönem Katsayıları } \\
\hline Değişken & \begin{tabular}{|l|} 
Katsayı \\
\end{tabular} & Standart Hata & t-istatistik & \begin{tabular}{|l|} 
Olasılık \\
\end{tabular} \\
\hline HSUK & 0,00000000022 & 0,00000000006 & 3,66313 & 0,0019 \\
\hline HTAH & 0,00000000001 & 0,00000000002 & 0,32828 & 0,7467 \\
\hline dKBSUK & $-0,00000000257$ & 0,00000000078 & $-3,292071$ & 0,0043 \\
\hline dOSTAH & 0,00000000001 & 0,00000000011 & $-0,138645$ & 0,8914 \\
\hline dKREDI & 0,00000002620 & 0,00000001080 & 2,415675 & 0,0272 \\
\hline $\mathrm{C}$ & $-4,03876500000$ & 9,30251600000 & $-0,434158$ & 0,6696 \\
\hline
\end{tabular}

Tablo 7'den kısa ve uzun dönem analiz sonuçları incelendiğinde, hazine sukuk ihracının hem kısa dönem hem de uzun dönem katsayılarının anlamlı olması, büyüme ile hazine sukuk ihracı (HSuk) arasında doğrusal bir ilişkiye işaret etmektedir. Ayrıca kısa dönemde hazine sukuk ihracının ilk dönemlerinde büyüme negatif etkilenirken, uzun dönemde hazine sukuk ihracının büyüme üzerinde pozitif etkisi olduğu görülmektedir. Katılım bankaları sukuk ihraçlarının (KBSuk) da büyüme ile arasında doğrusal ilişki vardır. İlaveten katılım bankaları sukuk ihracının büyüme üzerindeki negatif etkisinin uzun dönemde hafiflediği, katsayı değerinden anlaşılmaktadır. Diğer yandan, kısa dönem katsayılarının anlamsız olup uzun dönem katsayılarının anlamlı olması, krediler ile büyüme arasında doğrusal olmayan bir ilişkiye işaret etmektedir. Son olarak, kısa dönemde büyümeyi negatif etkileyen kredilerin, uzun dönemde büyümeyi pozitif etkilediği, katsayı değişiminden anlaşılmaktadır. Tüm bu sonuçlara karşın hazine tahvil ihracı (HTah) ve özel sektör tahvil ihracı (OSTah) ile büyüme arasında anlamlı bir ilişki olmadığı anlaşılmıştır. 
Bu bağlamda, Denklem 2 eşitliği Tablo 7'de yer alan uzun dönem katsayılarına göre tekrar uyarlanarak Denklem 3 'te yer almaktadır.

$$
\begin{aligned}
& \Delta Y=-4,038765+0,00000000022 \mathrm{HSuk}+0,00000000001 \mathrm{HTah}- \\
& 0,00000000257 \mathrm{KBSuk}+0,000000000010 \mathrm{STah}+0,00000002620 \text { Kredi }
\end{aligned}
$$

Hazine sukuk ihracı (HSuk) ve krediler ile büyüme arasında uzun dönemde pozitif ilişki varken, katılım bankaları tarafından ihraç edilen sukuk (KBSuk) ile büyüme arasında uzun dönemde negatif ilişki vardır. Bu doğrultuda, Hazine sukuk ihracında 1 TL'lik artış büyümeyi 0,00000000022 oranında, kredilerdeki 1 TL'lik artış ise büyümeyi 0,00000002620 oranında artırmaktadır. Buna karşın, katılım bankaları sukuk ihracındaki 1 TL'lik artış büyümeyi 0,00000000257 oranında yavaşlatmaktadır.

\section{Tartışma ve Öneriler}

Ekonomik çıktının makroekonomik belirleyicileri tüketim, yatırım, devlet harcamaları ve net dış ticaret dengesidir. Hazinenin ihraç ettiği sukuk ve tahviller, yatırım ve devlet harcamalarını etkilemektedir. Diğer yandan özel sektörün ihraç etmiş olduğu sukuk ve tahviller ise yatırım ve diş ticareti etkilemektedir. Krediler ise tüketim, yatırım ve dış ticareti etkilemektedir. Dolayısıyla modelde yer alan dinamik açıklayıcı değişkenler, ekonomik büyüme ile dolaylı olarak ilişki içindedir. Kontrol değişkenler ise ekonomik büyümenin fonksiyonunu oluşturmaktadır. Bu ilişkilerin temel dinamiğini anlamak üzere, çalışmamızda kullanılan makroekonomik değişkenlerin GSYİH'deki paylarının 2010-2019 arası dönem için hesaplanmış hali Şekil 4'te yer almaktadır.

\section{Şekil: 4 \\ Makroekonomik Değişkenlerin GSYİH'deki Payı, 2010-2019}

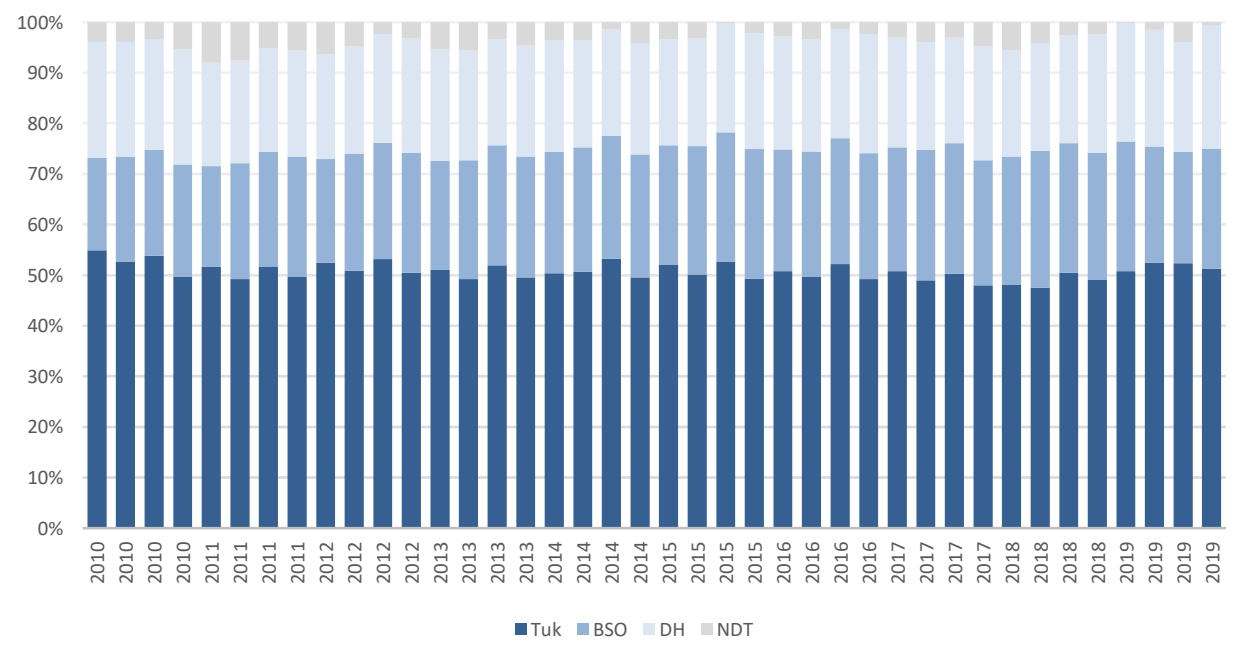

Kaynak: TÜIK, Merkezi Dağıtım Sistemi, Dönemsel Hesaplar. 
Orhan, Z.H. \& N. Tırman (2021), “Türkiye'deki Kira Sertifikası (Sukuk) İhraçlarının Büyüme

Üzerindeki Etkisine Dair Ampirik Bir Analiz: 2010-2019”, Sosyoekonomi, 29(48), 229-247.

Şekil 4'ten de görüldüğü üzere, makroekonomik değişkenlerin payı y1llara göre farklılık gösterse de ortalama ağırlıkları değişmemiştir. Buna göre Türkiye GSYİH'sinin yaklaşık olarak; \%50-55'ini tüketim harcamaları (Tuk), \%20-25'ini brüt sermaye oluşumu (BSO), \%20-25'ini devlet harcamaları (DH) ve \%0,5-3'ünü net diş ticaret (NDT) oluşturmaktadır.

Bu bağlamda, krediler, tüketim, yatırım ve dış ticaretin finansmanı kapsamında Türkiye GSYİH'sinin yaklaşık \%75'ine hitap etmektedir. Diğer yandan, hazine tarafindan ihraç edilen tahvil ve kira sertifikaları, devlet harcamaları ve yatırımların finansmanı kapsamında GSYİH'nin \%50'ine, özel sektör tarafından ihraç edilen tahvilat ve sukuklar ise yatırım ve dış ticaretin finansmanı kapsamında GSYİH’nin yaklaşık \%25'ine karşılık gelmektedir. Dolayısıyla, krediler tek başına Türkiye GSYİH'sinin büyük bir kısmını etkilemektedir. Buna paralel olarak, Denklem 3 'te yer alan değişkenler arasından da krediler Türkiye GSYİH büyümesindeki en yüksek etkiye sahiptir (0,00000002620).

Bu noktada bir önceki bölümde yer alan ampirik analizin sonuçlarını yorumlamaya geçecek olursak; Tablo 7'de yer alan nihai sonuçlar arasında öne çıkan bir tanesi, hazine ve özel tahvil ihraçlarının büyüme üzerinde anlamlı bir etkisinin olmamasıdır. Bunun olası sebeplerini araştırmak için ilgili literatüre başvurulduğunda çok fazla doğrudan çalışma yapılmadığg görülecektir. Wanjiru (2015), yayımlanmamış yüksek lisans tezinde 2001-2014 arası dönem için Kenya'yı incelemiş, hazine tahvili piyasasının GSYİH üzerindeki etkisinin kontrol değişkenler eklendikten sonra anlamsız çıktığını bulgulamıştır. Bunun temel sebebi olarak da tahvil piyasasının henüz diğer değişkenler kadar etkin olmamasını göstermiştir. Her ne kadar biz bu çalışmamızda benzer bir sonuç elde etsek de çıkan sonucu hazine tahvil piyasasının az gelişmişliğine yormamız pek mümkün gözükmemektedir. Bununla birlikte, diğer kontrol değişkenlerin (örneğin, enflasyon, dış ticaret haddi ve kredilerin) etkisinin tahvillerden daha fazla olması bu çalışma için de söz konusu olabilir.

Öte yandan, Matiti (2013) tarafından yine Kenya üzerinde yapılan çalışmada ise devlet tahvilinin büyüme üzerinde pozitif etki yaptığı saptanmıştır. Fakat burada kullanılan model daha basit kapsamlıdır. Bu noktada borçlanma kâğıtları olan tahvillerin iç ve dış borçlanma üzerine olup olmadığ 1 da önem arz etmektedir. Al Kharusi ve Ada (2018), 1990 2005 arası dönemde Umman için bir ekonometrik analiz yapmışlar ve neticede tahvillere dayalı dış borcun ekonomik büyüme üzerinde negatif etkisi olduğu sonucuna varmışlardır. Dar ve Amirkhalkhali (2014) de 23 OECD (Organisation for Economic Co-operation and Development) ülkesini 1996-2007 arası dönem için inceleyerek benzer bir sonuca varmıştır. Fakat burada negatif bulunan etki ufak ve istatistiksel olarak anlamsızdır. Biz bu çalışmamızda yalnızca iç borçluluğu temsil eden devlet iç borçlanma senetlerini analize dâhil ettik. Dolayısıyla sonuçlar, dış borçluluğu (eurobond/eurosukuk) kapsamamaktadır.

Tablo 7 ve Denklem 3 'te ortaya konan bir başka önemli sonuç, tahvilin aksine hazine ve katılım bankacılığı sukuk ihraçlarının büyüme üzerinde anlamlı bir etkisinin olmasıdır. Nitekim bu husus, araştırmamızın da temel amacını oluşturmaktadır. Buna göre büyüme üzerinde anlamlı ve pozitif etki yapan sukuk türü, hazine sukukudur (HSuk). Fakat söz konusu etki oldukça ufaktır (0.00000000022). Katılım bankaları tarafından ihraç edilen 
sukukların (KBSuk) büyüme üzerindeki etkisi ise anlamlı ve negatiftir. Fakat etki yine ufak çaplıdır (-0.00000000257). Öncelikle, bu etkilerin ufak çaplı olması, ekonominin büyüklüğüyle karşılaştırıldığında sukuk ihraçlarının ufak boyutlarda kalmasıyla ilişkilendirilebilir. İlaveten, tam işlem hacmi miktarlarıyla analiz yapılmış olması da katsayıların ufak kalmasına sebep olmuştur denebilir. İkinci olarak, hazine sukuk ihraçlarının etkisinin pozitif iken katılım bankaları tarafından yapılan sukuk ihraçlarının etkisinin negatif olması ayrıca önemli bir sonuçtur. Bunun bir sebebi, hazine sukuklarının özel sukuk ihraçlarına nazaran daha büyük hacimli olması ve yöneldiği alanların farklılığı olabilir. Bu sonuç, özellikle devlet tarafından basılan sukukun büyüme üzerinde olumlu etki yaptığını bulgulayan Mitsaliyandito vd. (2017) ile benzerlik taşımaktadır. Buradan çıkan sonuca göre, eğer büyüme üzerinde olumlu etki yapması arzu ediliyorsa özellikle hazine sukukuna öncelik tanınması yönünde bir öneride bulunulabilir.

Ancak Tablo 7'nin ortaya koyduğu şu sonucun da göz ard1 edilmemesi gerekir: Katılım bankalarının ihraç ettiği sukukun büyüme üzerindeki negatif etkisinin uzun vadede hafiflemesi söz konusudur. Buna göre Tablo 1'de yer alan senelik sukuk ihracı rakamları özellikle son iki senede katlanarak artmaktadır. Dolayısıyla, Türkiye'de henüz gelişmeye başlayan sukuk piyasası ile katılım bankaları tarafından ihraç edilen sukukun da büyümeye olumlu katkısı gelecek zamanlarda muhtemeldir.

Son olarak, eğer sukuk ihraçlarının hem etki hem işlev bakımından kendisini tahvilden farklılaştırması amaçlanıyorsa katılım bankaları nezdindeki ihraçların niteliği ve etkinliğinin artırılması gerekmektedir. $\mathrm{Bu}$ ise bir başka çalışmanın konusunu oluşturmaktadır.

\section{Sonuç}

Bu makale, dünyada 1970’lerin sonundan itibaren kullanılmaya başlanan sukuk enstrümanının büyüme üzerindeki etkisine dairdir. Konunun önemi, 1970'lerin başından itibaren dünyada giderek gelişen bir alan olan İslâmî fỉnansın bugün için öne çıkan unsurlarından bir tanesini oluşturan sukukun reel anlamda ekonomiye katkısının incelenmesine dayanmaktadır. Benzeri çalışmaların gerek Türkiye gerekse dünyada çok seyrek olması, çalışmanın önemini ortaya koyan bir başka husustur.

Bu kapsamda, Türkiye'de kira sertifikası olarak bilinen ve 2010 yılından itibaren ihraç edilen sukuk enstrümanının Türkiye'deki büyümeye etkisi ekonometrik analize tabi tutulmuştur. Söz konusu analiz gerçekleştirilirken ARDL modeli kullanılmış, büyümeye etki edebileceği öngörülen diğer temel unsurlar (kredi, enflasyon, tüketim, brüt sermaye oluşumu, devlet harcamaları ve net diş ticaret) kontrol değişkenler olarak modele eklenerek 2010-2019 arası dönem için çeyrek dönemler üzerinden analiz gerçekleştirilmiştir.

Analiz sonucunda şu gibi temel sonuçlara erişilmiştir: Hazine ve özel sektör tahvilinin aksine hazine ve katılım bankacılığı sukuk ihraçları büyüme üzerinde anlamlı bir etkiye sahiptir. Fakat bunlardan büyüme üzerinde anlamlı ve pozitif etki yapan sukuk türü hazine sukuku iken katılım bankaları tarafından ihraç edilen sukukların büyüme üzerindeki etkisi anlamlı fakat negatiftir. Daha detayında, hazine sukuk ihracı büyüme oranını 
0.00000000022 artırırken katılım bankacılığg sukuk ihracı büyümeyi 0.00000000257 azaltmaktadır. Her iki durumda da etkinin oldukça ufak kaldığı görülmektedir. Bunun temel bir sebebi, ekonominin büyüklüğü ile orantılandırıldığında sukuk ihracı hacimlerinin ufak kalması olabilir. Nitekim Türkiye için bir çalışma yapmış olan Alkhawaja (a.g.e.), bu oranların 2010 ve 2017 için \%0.013 ve \%0.544 olduğunu ortaya koymuştur. Türkiye'yi kapsayan diğer ilgili çalışmalardaki sonuçlar toplu bir şekilde verilip Türkiye özelinde çıkarım yapılmadığ 1 için burada bizim çalışmamızla mukayese edilmeleri zor olmakla birlikte genel itibariyle Türkiye'nin kalkınmakta olan ülkelerle birlikte sukuk ihraçlarının büyüme ile pozitif ilişkiye sahip olduğu bulgulanmaktadır (Yıldırım vd., 2020, Avci, 2020). Fakat bu çalışmalarda sukuk ihracı türleri için ayrıca bir değerlendirilme yapılmamaktadır. Oysa sukuk ihraçları içerisinde özellikle hazine sukuklarının öne çıkması söz konusudur. Nitekim analizimiz sonucunda hazine sukuku etkisinin pozitif, özel sektör sukuku etkisinin negatif çıkmasının bir sebebi olarak bu gösterilebilir. Benzer bir bulgu, Mitsaliyandito vd. (a.g.e.) tarafından ortaya konmuştur.

\section{Kaynaklar}

AAOIFI (2018), "Investment in Sukuk, Shares and Similar Investments", Finansal Muhasebe Standardl, No. 1/2018, <http://aaoifi.com/fas-25-investments-in-sukuk-shares-andsimilar-instruments/?lang=en>, 23.02.2020.

Ahmad, N. \& S.N.M. Daud \& Z. Kefeli (2012), "Economic Factors and the Sukuk Market", Procedia-Social and Behavioral Sciences, (65), 127-133.

Aktepe, İ.E. (2013), Sorularla Katılım Bankacılı̆̆ı, İstanbul: TKBB.

Al-Kharusi, S. \& M.S. Ada (2018), "External Debt and Economic Growth: The Case of Emerging Economy”, Journal of Economic Integration, 33(1), 1141-1157.

Alkhawaja, M.I. (2019), "Sukuk: Measuring the Role of Sukuk as an Economic Growth Enhancer in Turkey", Australian Journal of Basic and Applied Sciences, 13(2), 95-99.

Al-Raeai, A.M. \& Z. Zainol \& A.K.B. Abdul Rahim (2018), “The Role of Macroeconomic Factors on Sukuk Market Development of Gulf Cooperation Council (GCC) Countries", International Journal of Economics and Financial Issues, 8(3), 333-339.

Bashir, M.S. (2010), "Islamic Finance and Its Contribution to Solving the Current Financial Crisis", International Journal of Knowledge Management Studies, 1(17), 85-99.

Bayındır, S. (2015), Fıkhi ve İktisadi Açıdan Íslâmî Finans, İstanbul: Süleymaniye Vakfı Yay.

Çil, N. (2018), Finansal Ekonometri, İstanbul: Der Yay.

Dar, A. \& S. Amirkhalklali (2014), “On the Impact of Public Debt on Economic Growth”, Applied

Econometrics and International Development, 14(1), 21-32.

Dede, K. (2017), Katılım Bankalarında Hazine Ürünleri ve Sermaye Piyasası Uygulamaları, İstanbul: TKBB Yay.

Echchabi, A. \& H. Abd.Aziz \& U. Idriss (2016), "Does Sukuk Financing Promote Economic Growth? An Emphasis on the Major Issuing Countries", Turkish Journal of Islamic Economics, 3(2), 63-73.

Enders, W. (1995), Applied Econometric Time Series, New York: Wiley John Wiley \& Sons, Inc.

Fahrian, D. \& C. Seftarita (2016), "The Effects of Sukuk (Islamic Bonds) in the Economy", Proceedings of the 6th Annuual International Conference Syiah Kuala University (AIC 
Unsyiah) in conjunction with The 12th International Conference on Mathematics, Statistics and Its Application (ICMSA) 2016, October 4-6, 2016, Banda Aceh, Indonesia.

Hussain, H.A.B.N. \& A. Abideen \& E.R. Adawiah (2018), "Factors Influencing Issuer's Sukuk Structure Preference: The Case Study of KSA Banks", Journal of Islamic Finance, 7(1), 51-57.

IFSB (2019), "Islamic Financial Services”, Industry Stability Report, Kuala Lumpur: IFSB.

Kantarc1, H.B. \& T. Eren (2018), “The Emergence of Sukuk Market and Economic Effects”, Global Journal of Emerging Trends in e-Business, Marketing and Consumer Psychology (GJETeMCP), 4(1), 595-601.

Malikov, A. (2017), "How Do Sovereign Sukuk Impact on the Economic Growth of Developing Countries? An Analysis of the Infrastructure Sector", içinde: V. Efendić vd. (eds.), Critical Issues and Challenges in Islamic Economics and Finance Development, Springer International Publ.

Matiti, C. (2013), "The Relationship between Public Debt and Economic Growth in Kenya", International Journal of Social Sciences and Project Planning Management, 1(1), 1-21.

Mitsaliyandito, R.Q. \& T. Arundina \& R.A. Kasri (2017), "Impact of Sukuk Market Development on Indonesian Economic Growth", International Journal of Applied Business and Economic Research, 15(3), 1-13.

Moshenskyi, S. (2008), History of the Weksel: Bill of Exchange and Promissory Note, Xlibris Corporation.

Onagun, A.I. (2016), “The Impact of Sukuk in Developing UAE Economy”, Journal of Islamic Banking and Finance, 2016(Oct-Dec), 71-85.

Pesaran, M.H. \& Y. Shin \& R. Smith (2001), "Bounds Testing Approaches to the Analysis of Level Relationship", Journal of Applied Econometrics, 16(3), 289-326.

Pesaran, M.H. \& Y. Shin (1999), “An autoregressive distributed-lag modelling approach to cointegration analysis", Econometric Society Monographs, 31(7), 371-413.

Smaoui, H. \& S. Nechi (2017), “Does Sukuk Market Development Spur Economic Growth?”, Research in International Business and Finance, (41), 136-147.

T.C. Hazine ve Maliye Bakanlığı (HMB), Kamu Finansmanı Ístatistikleri, <https://www.hmb.gov.tr/kamu-finansmani-istatistikleri>, 02.03.2020.

T.C. Merkez Bankası (TCMB), Elektronik Veri Dağıtım Sistemi (EVDS), <https://evds2.tcmb.gov.tr/index.php?/evds/serieMarket\#collapse_4>, 02.03.2020.

Türkiye İstatistik Kurumu (TÜİK) Merkezi Dağıtım Sistemi, Dönemsel Hesaplar, <https://biruni.tuik.gov.tr/medas/?kn=88\&locale=tr>, 02.03.2020.

Türkiye İstatistik Kurumu (TÜİK), Tüketici Fiyat Endeksi $(2003=100)$, <http://www.tuik.gov.tr/UstMenu.do?metod=temelist>, 02.03.2020.

Türkiye Katılım Bankaları Birliği (TKBB), Sukuk İhraçları, <https://www.tkbb.org.tr/digeristatistikler>, 02.03.2020.

Wanjiru, K.M. (2015), "The Impact of Treasury Bond Market Development on Economic Growth in Kenya”, Basılmamış Yüksek Lisans Tezi, Nairobi Üniversitesi.

Yıldırım, S. \& D.C. Yıldırım \& P. Diboglu (2020), "Does Sukuk market development promote economic grwoth?", PSU Research Review, https://doi.org/10.1108/PRR-03-2020-0011, 02.03.2020. 
Orhan, Z.H. \& N. Tırman (2021), “Türkiye'deki Kira Sertifikası (Sukuk) İhraçlarının Büyüme Üzerindeki Etkisine Dair Ampirik Bir Analiz: 2010-2019”, Sosyoekonomi, 29(48), 229-247. 